\title{
Enhancing Biogas Production: Influence of Mixing Cow and Chicken Manures
}

\author{
Essam Ibrahim Hammad, Mohammad R. Al-Agha, Yasser El-Nahhal* \\ Department of Earth and Environment, Faculty of Science, The Islamic University of Gaza, Gaza, Palestine \\ Email: *y_el_nahhal@hotmail.com
}

How to cite this paper: Hammad, E.I., Al-Agha, M.R. and El-Nahhal, Y. (2018) Enhancing Biogas Production: Influence of Mixing Cow and Chicken Manures. Energy and Power Engineering, 10, 383-397. https://doi.org/10.4236/epe.2018.108024

Received: July 19, 2018

Accepted: August 25, 2018

Published: August 28, 2018

Copyright $\odot 2018$ by authors and Scientific Research Publishing Inc. This work is licensed under the Creative Commons Attribution International License (CC BY 4.0).

http://creativecommons.org/licenses/by/4.0/

(c) (i) Open Access

\begin{abstract}
The objectives of this study were to enhance the production of biogas through using a mixture of cow and chicken manure and to investigate the effect of digested manure on plant growth. Biogas digester consisted of a plastic polyethylene tank with a volume of 0.25 cubic meters. Cow and chicken manures were collected from certified animal and chicken farms. Mixture of manure was prepared by mixing $5 \mathrm{~kg}$ of chicken manure and $5 \mathrm{~kg}$ of cow manure together in $100 \mathrm{~L}$ plastic tank containing $90 \mathrm{~L}$ water free from chlorine. Percentage of manure in all cases was $10 \%(\mathrm{w} / \mathrm{v})$. The manures were transferred to the digesters and kept in greenhouse to insure warm conditions $\left(30^{\circ} \mathrm{C}-39^{\circ} \mathrm{C}\right)$. Produced biogas was measured each two days and digestate samples were taken every two days for $\mathrm{pH}, \mathrm{EC}, \mathrm{BOD}, \mathrm{COD}$ determination. Results showed increased biogas production and reached the highest quantity after 28 days and the amount of biogas produced from the mixture of cow and chicken manures was higher than the amount produced from each manure individually. Decreases in $\mathrm{pH}$ values were observed during biogas production followed by BOD, COD reduction. On the other hand, increases on EC values were observed. Application of digested manure in agriculture increased yield of lettuce by $75 \%$ comparing with the control sample. The study recommended using cow manure mixed with chicken manure to increase the production of biogas and to use the digested manure in agricultural.
\end{abstract}

\section{Keywords}

Biogas, Cow Manure, Chicken Manure, Digested Manure

\section{Introduction}

Rapid growth of population and development in industrial activities require large quantities of energy, and on the other hand, generate large quantities of waste that should adequately be disposed without risks to human life and eco- 
systems [1]. Biogas production is an alternative source of energy production throughout converting chemical energy in different organic wastes to thermal energy. So far biogas production occurred through biochemical degradation of organic wastes using different types of non-aerobic bacteria. Biomass contributes around $(10 \%-14 \%)$ of the world's energy supply and anaerobic digestion of the cattle manure has been studied by various people and found to be successful [2]. Gas production is a function of residence time of bacteria. For instance, Laskri and Nedyah [3] studied biogas production from different waste and found that the volume of biogas produced is always a function of the residence time of digestion and the concentration of organic matter in the experiment. In addition, Al-Hamamre, et al. [4] evaluated the status of biomass energy in Jordan and revealed that the amount of biogas that can be produced from various biomass sources is estimated of 428 MCM. Furthermore, Al-Jabri, et al. [5] studied the generation of biogas from bio-waste in rural area of Palestine. They showed that biogas can be generated in a big quantity in rural area of Palestine using the Indian biogas model. Furthermore, Maranon, et al. [6] evaluated the co-digestion of cattle manure with food waste and study to increase biogas production. They found a decreased methane production when increasing the organic load rate and decreasing high retention time. In a different study, Esposito, et al. [7] evaluated the enhanced bio-methane production from co-digestion of different organic wastes, they found that mixing buffalo manure with organic fraction of the municipal solid waste resulted in $12 \%$ and $30 \%$ high methane volume after 30 and 15 days from the test start respectively. In a different location, Hammed et al. [8] revealed that conversion of animal waste into biogas has the potential to meet the needs of $20 \%$ of the rural population. Moreover, Al-Amin, et al. [9] quantified the biogas production and indicated a production rate of $0.63 \mathrm{~m}^{3}$ biogas $/ \mathrm{m}^{3}$ agricultural wastes. Previous authors [10] [11] described the construction and production of biomass digesters.

The limitation of the abovementioned reports is that they focused on evaluating the biogas from one type of manure. They did not evaluate mixtures of manure in biogas production. Furthermore, they did not make biogas purification or using the digested manure as a fertilizer. Furthermore, quantification of biogas production remains poorly investigated. The authors of this study focused their efforts on evaluating the effects of mixing manure on the quantity of biogas production and further provided a chemical technique for biogas production and investigated the digested materials as fertilizers.

\section{Materials and Methods}

The fresh cow manure and poultry manures were collected from certified cow and poultry farms in Gaza Strip. About $100 \mathrm{~kg}$ slurry in a ratio of 1:9 of manure and water each were taken and mixed well to form a homogenous mixture as shown below: treatment 1 contains $10 \%$ cow manure $+90 \%$ water; treatment 2 , contains $10 \%$ poultry manure $+90 \%$ water and treatment 3 contains $5 \%$ cow manure $+5 \%$ poultry manure $+90 \%$ water. These three mixtures were trans- 
ferred into three plastic polyethylene tank of $250 \mathrm{~L}$ capacity each.

\subsection{Description of the Biodigesters}

A basic biogas digester consists of a plastic polyethylene tank of $250 \mathrm{~L}$ capacity each, purchased from a local market. The biogas design is shown in Figure 1.

\subsection{Operation of Biogas}

A homogenized manure prepared according to the above mentioned ration was added to digester through an inlet and be removed after complete digestion from the outlet in the bottom of digester. The digester was $95 \%$ filled with manure homogenate. The oxygen in the $5 \%$ air was consumed by burning a small was on a plastic plate under closed condition.

The wax will be turned off immediately after complete consumption of oxygen occurred.

Temperature of digester was measured by using pie inserted in digester. The upper cover of digester is attached with a plastic tube to collect the produced biogas into a big elastic bag.

\subsection{Purification of the Biogas}

The collected biogas was allowed to pass into three containers for complete purification. The $1^{\text {st }}$ container contained ferric oxide that reacts with hydrogen sulfide. The $2^{\text {nd }}$ container contained calcium hydroxide the react with $\mathrm{CO}_{2}$ to form $\mathrm{CaCO}_{3}$. The $3^{\text {rd }}$ container contained Boric acid that react with $\mathrm{NH}_{3}$ or $\mathrm{NH}_{4} \mathrm{OH}$ (Figure 1).

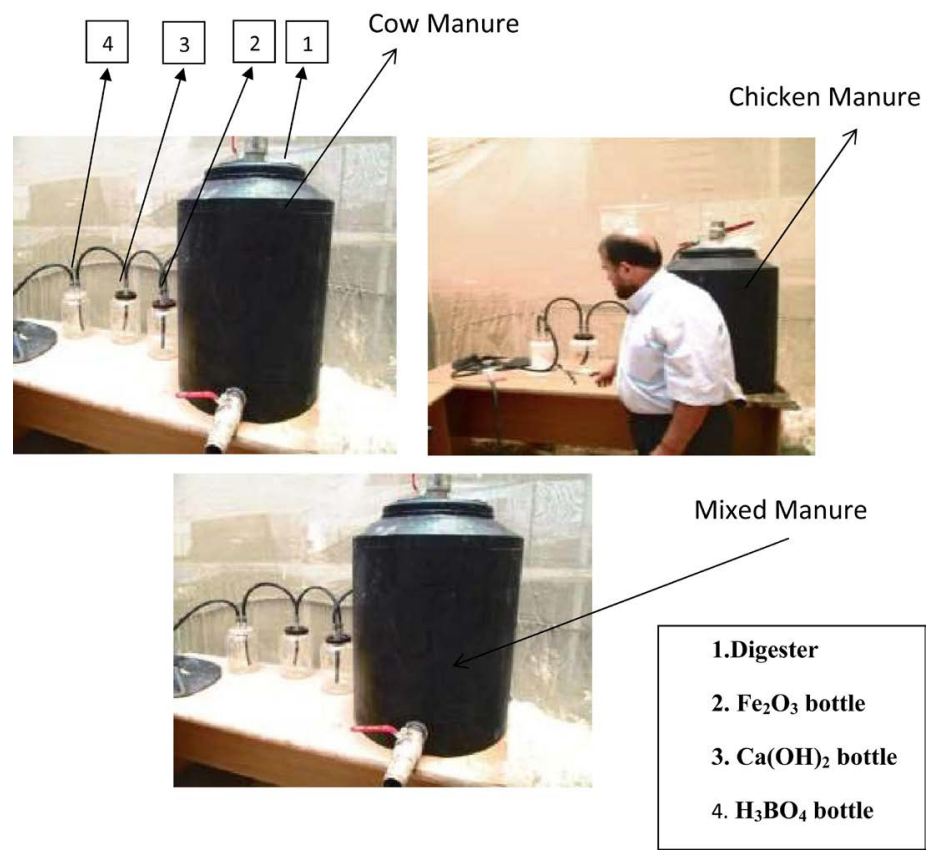

Figure 1. The structure and components of biogas production system. The numbers on bottles are shown in the legend of the graph. 


\subsection{Sampling of Digestant}

Samples of the manures were taken before starting biogas production and after 28 days of retention time from each plastic tank. Then samples were taken each two days for determination of acidity (pH), electric conductivity (EC), total solid (TS), chemical oxygen demand (COD), biological oxygen demand (BOD), phosphates $\left(\mathrm{PO}_{4}\right)$, sulfate $\left(\mathrm{SO}_{4}\right)$ and cations. The total kegldahl nitrogen (TKN) and total organic carbon (TOC) were determined in the initial and final digestion as previously reported [12] [13] [14]. All the parameters were analyzed and determined according to standard methods.

\subsection{Measurement of Produced Biogas}

The produced biogas was collected in a rubber bag pre-weighted before installation with the biogas production system, after complete filling of the rubber bag with biogas it was weighted again. The difference between the initial and final weights indicates the weight of the produced biogas. These steps were repeated each to days to weight the amount of produced biogas.

\subsection{Determination of Chemical Properties of Manures}

Following the procedures previously described [13] [14], pH, EC, TDS, COD, $\mathrm{BOD}$, were determined before and after biogas production in manure. Analysis before biogas production was performed to a representative manure sample $(1 \mathrm{~L}$ sample in triplicate) collected after complete mixing and homogenization, was done on the next day of sample collection.

At the end of biogas production, three $\mathrm{L}$ samples were collected from the outlet of the system (Figure 1) $1 \mathrm{~L}$ each were analyzed for the parameters mentioned above.

\subsection{Application of Digested Manure in Agriculture as Fertilizer}

Lettuce seedlings were sown in plastic pots $10 \mathrm{~L}$ containing $9 \mathrm{~kg}$ sand soil collected from an agricultural area has a free history of using organic or mineral fertilizers. The experimental design includes three treatments as follows: control sample includes lettuce seedling sown in 5 plastic pots and receiving only fresh water, treatment 1 includes lettuce seedlings sown in 5 plastic pots and receiving fresh manure (before biogas production), treatment 3 includes lettuce seedling sown in plastic pots receiving digested manure. The quantity of manure tested corresponded to the rate of $1 \mathrm{~kg} / \mathrm{m}^{2}$ of soil according to the recommendation of ministry of agriculture [15]. Fresh weight of lettuce after three weeks was taken as indicators of growth [16] [17] [18] [19] [20] or growth inhibition [21].

\subsection{Influence of Digested Manure on Soil and Plant Properties}

Based on previous published work [22] [23] [24] [25] [26] influence of digested manure on soil and plant properties were determined using the following equations 


$$
\% \text { Growth }=100 \times\left(L_{t}-L_{c}\right) / L_{t}
$$

where, $L_{t}$ and $L_{c}$ are the plant length/weight $(\mathrm{cm} / \mathrm{g})$ in the treatment and the control sample. Then $\%$ GI values were regressed with the tested.

\subsection{Statistical Analysis}

Average and standard deviation were calculated to each treatment. t-test was used to detect differences among treatment at $\mathrm{p}$-value $=0.05$ low value of standard deviation indicates homogenization and accuracy of the work. We included error bars in the figures where applicable. An overlapping of error bars indicates no significant differences. We also added letters in tables to indicate similarity of results.

\section{Results}

\subsection{Description of the Biodigesters}

The biodigesters are plastic tanks made of polyethylene to avoid broken down due to movements. They are usually back or blue to absorb heat energy during the operation process to accelerate biogas production.

\subsection{Operation of Biogas}

Immediately after mixing the manure as mentioned above, it was transferred to the biodigesters for incubation in the greenhouse at a temperature ranged from $25^{\circ} \mathrm{C}-30^{\circ} \mathrm{C}$ for $3-7$ days to start working. The volume of the plastic tube for biogas collection was taken as an indicator of system operation. As the volume increased rapidly as the operation process went smoothly.

\subsection{Purification of the Biogas}

The process included passing the produced biogas along with the impurities to the purification system which consisted of three units connected directly to gather as seen in Figure 1. Each unit contained specific material that can react only with one impurity. For instance, the impurities generated with the biogas are carbon dioxide $\left(\mathrm{CO}_{2}\right)$, hydrogen sulfide $\left(\mathrm{H}_{2} \mathrm{~S}\right)$ and ammonia. These impurities passed along with the biogas $\left(\mathrm{CH}_{4}\right)$ the containers. One container contained calcium hydroxide to remove $\mathrm{CO}_{2}$, the second container contained ferric metal to remove hydrogen sulfide and the third container contained Boric acid to remove ammonia. By this way we insure purification of biogas.

\subsection{Sampling of Digestate}

Sampling of Digestate was performed each two days to understand the effect of time on the biogas production.

\subsection{Measurement of Produced Biogas}

The collected gas during 28 days in two days' period is presented in Figure 2. It is obvious that the produced gas is increased in due time in the three systems. It 


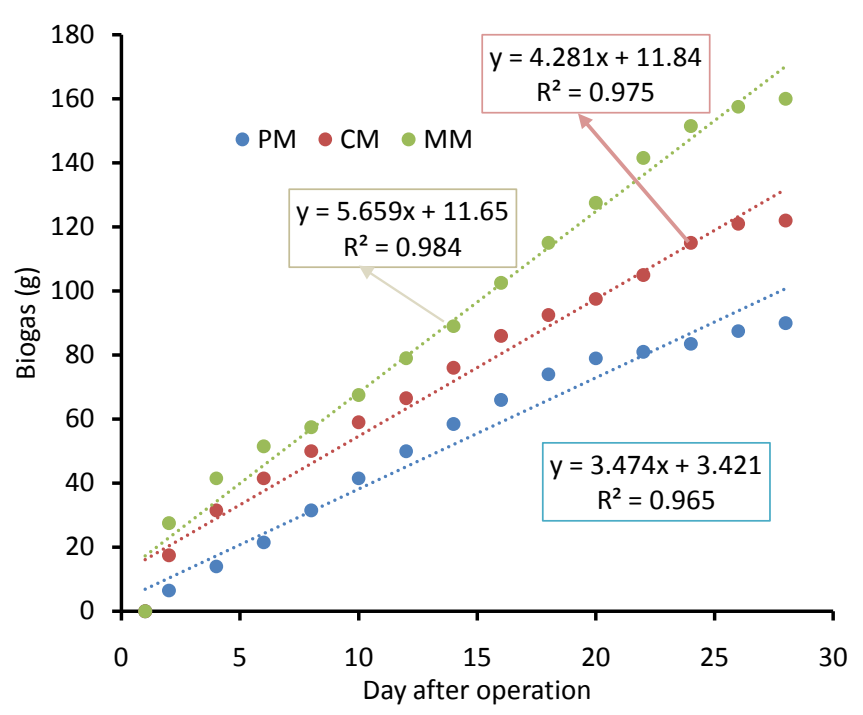

Figure 2. Biogas production from three types of manures. The values presented are average of treatment.

can be seen that mixture of manure produced higher quantity of biogas than cow or poultry manure. This indicates that mixing manure would be an optimal choice for biogas production.

\subsection{Determination of Physico-Chemical Properties of Digestant}

\subsubsection{Profile of Acidity ( $\mathrm{pH})$ in the Digestion Units}

Daily measurements of $\mathrm{pH}$ values of the manure during the gas production period are shown in Table 1. It can be seen that cow manure, chicken manure and mixed manure have $\mathrm{pH}$ ranges of $(7.98$ - 7.58), (8.50 - 8.20) and (7.97 - 7.50) respectively.

It can be seen that all $\mathrm{pH}$ ranges declined to a more acidic value during the biogas production regardless to the alkalinity range.

\subsubsection{Total Solid (TS)}

The values of TS of the manures are presented in Figure 3. It can be noticed that TS values are high at time zero (beginning) and reduced to the lowest measured value at 28 day after operation. This indicates that TS value is being consumed during biogas production.

\subsubsection{Electric Conductivity (EC)}

Measured values of EC in manure are presented in Figure 4. The values are increased gradually and reached the maximum after 28 day of operation.

The insoluble large molecules consist of many small molecules joined together by chemical bonds and thus need to be hydrolysis before entering the bacterial cell, the hydrolysis step is carried out by several different anaerobic and facultative bacteria, the results of very small components with ionic characteristic, so the conductivity of the manure salary with increase gradually, by increase the decomposition, E.C for the three reactors increases. 
Table 1. $\mathrm{pH}$ profile during biogas production (Avg \pm Stdev).

\begin{tabular}{cccc}
\hline Time (days) & Cow manure & Chicken manure & Mixed manure \\
\hline 0 & $7.97 \pm 0.02$ & $8.50 \pm 0$ & $7.97 \pm 0$ \\
2 & $7.93 \pm 0.04$ & $8.50 \pm 0$ & $7.97 \pm 0.01$ \\
4 & $7.88 \pm 0.04$ & $8.49 \pm 0.01$ & $7.96 \pm 0.01$ \\
6 & $7.83 \pm 0.04$ & $8.48 \pm 0$ & $7.97 \pm 0.02$ \\
8 & $7.78 \pm 0.04$ & $8.45 \pm 0.04$ & $7.89 \pm 0.13$ \\
10 & $7.74 \pm 0.02$ & $8.41 \pm 0.01$ & $7.77 \pm 0.05$ \\
12 & $7.67 \pm 0.07$ & $8.40 \pm 0.01$ & $7.72 \pm 0.02$ \\
14 & $7.61 \pm 0.01$ & $8.40 \pm 0.12$ & $7.66 \pm 0.06$ \\
16 & $7.58 \pm 0.04$ & $8.39 \pm 0.01$ & $7.64 \pm 0.03$ \\
18 & $7.53 \pm 0.04$ & $8.33 \pm 0.08$ & $7.65 \pm 0.01$ \\
20 & $7.54 \pm 0.06$ & $8.27 \pm 0.01$ & $7.61 \pm 0.05$ \\
22 & $7.52 \pm 0.09$ & $8.23 \pm 0.04$ & $7.56 \pm 0.01$ \\
24 & $7.45 \pm 0.03$ & $8.20 \pm 0.07$ & $7.54 \pm 0.01$ \\
26 & $7.52 \pm 0.09$ & $8.20 \pm 0.1$ & $7.52 \pm 0.02$ \\
28 & $7.58 \pm 0.01$ & $8.20 \pm 0.01$ & $7.50 \pm 0.01$ \\
\hline
\end{tabular}

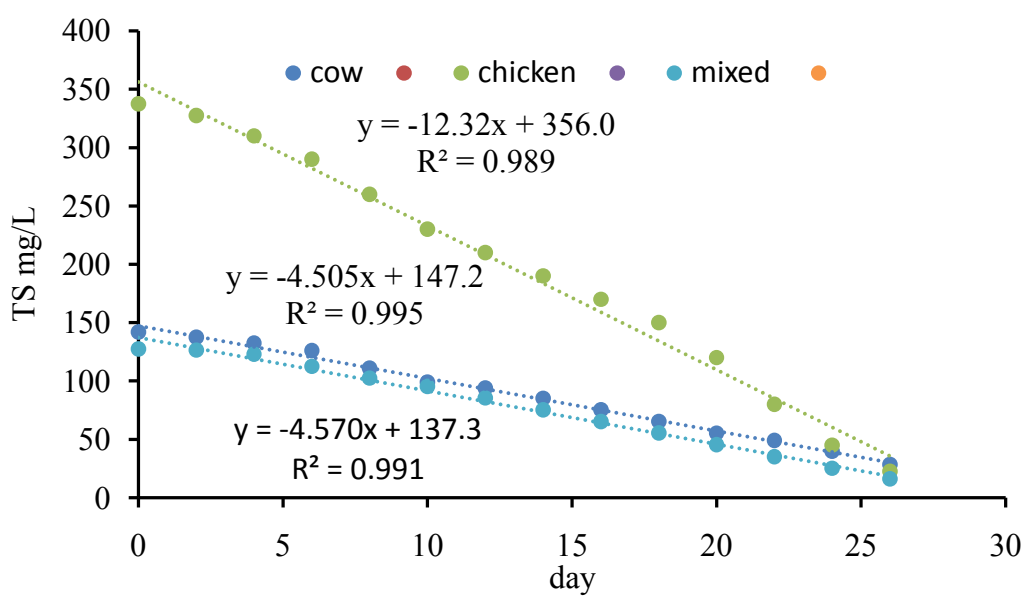

Figure 3. TS profile during biogas production. Values are average of three replicates of each treatments.

\subsubsection{Measurement of COD}

$\mathrm{COD}$ and $\mathrm{BOD}$ values are presented in Figure 5. It can be noticed that $\mathrm{COD}$ and $\mathrm{BOD}$ values are very high at the beginning time of biogas production then became at the lowest level after 28 day of biogas production.

This indicated that biogas production generated a bioremediation process of manure.

\subsection{Application of Digested Manure in Agriculture as Fertilizer}

Influence of digested manure on plant growth is shown in Table 2 and Figure 6. 


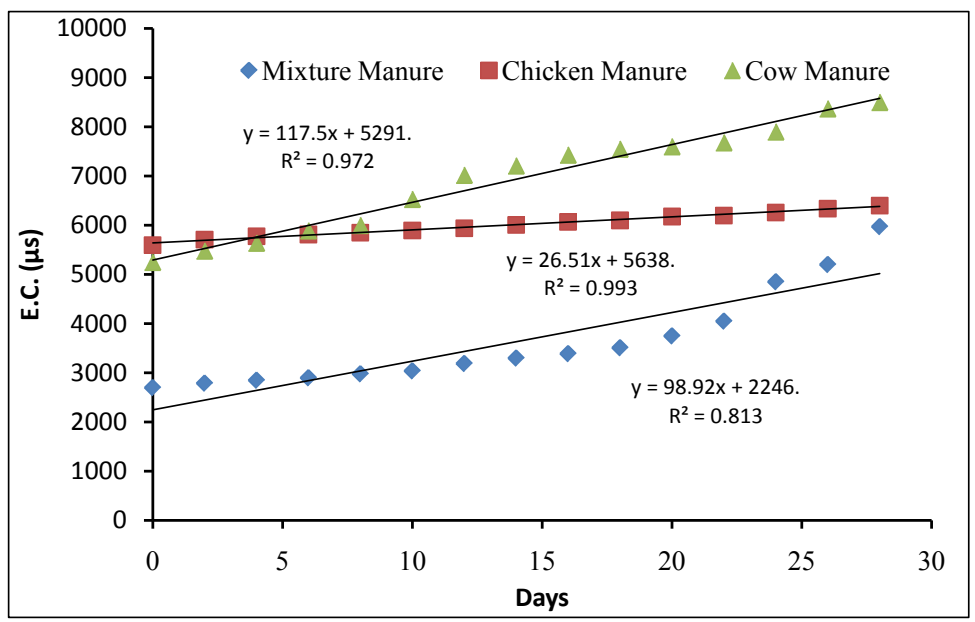

Figure 4. EC profile during biogas production. Values are average of three replicates of each treatments.
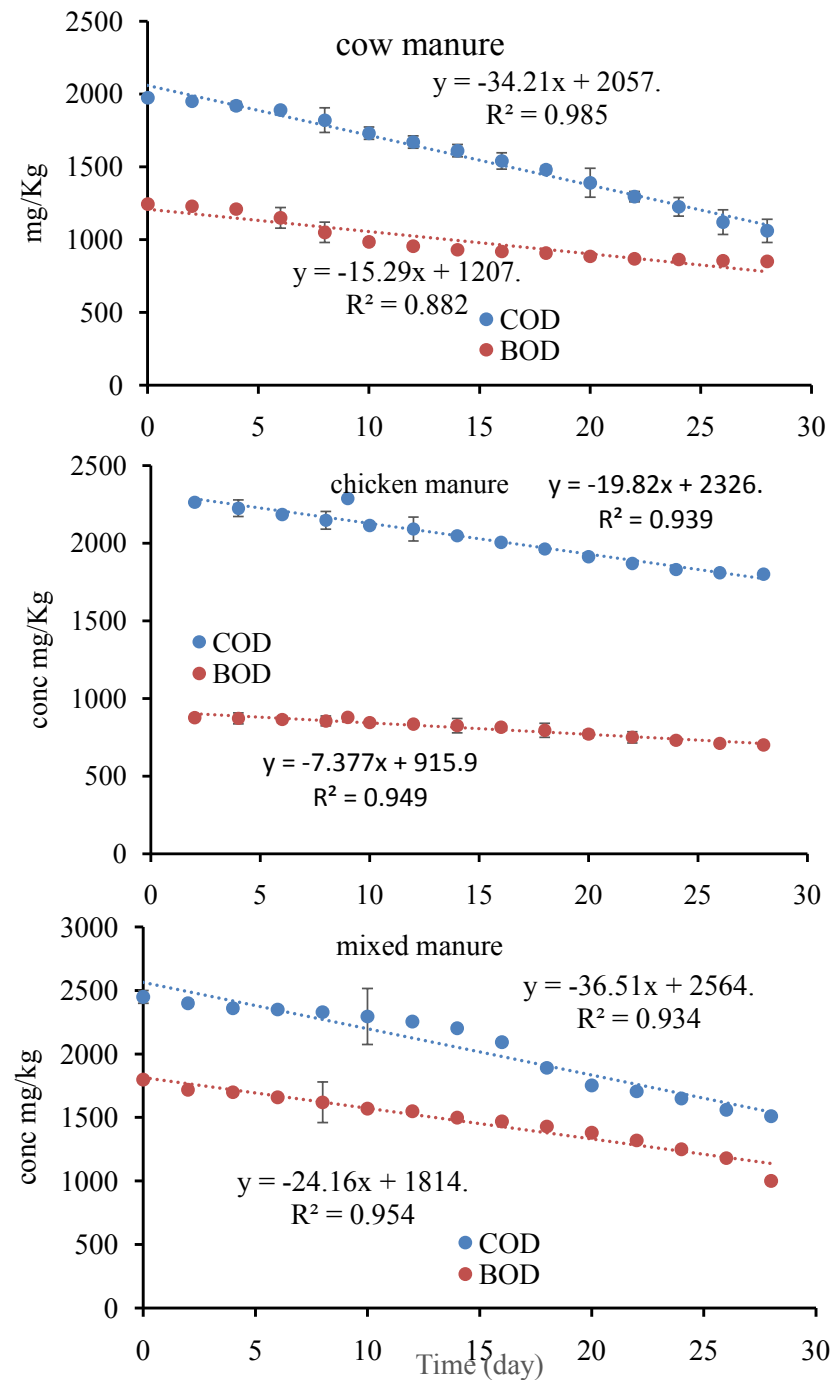

Figure 5. Levels of BOD and COD during production of biogas. Values are means and error bars represent standard deviation. 
Table 2. Present the properties quality of plant with and without addition of slurry.

\begin{tabular}{ccc}
\hline Properties & With Bio-Fertilizers & Without Bio-Fertilizers \\
\hline Weight & $950 \pm 50 \mathrm{~g}$ & $540 \pm 35 \mathrm{~g}$ \\
Color & Very Green & Dull and yellow \\
Leaf area & Large area & Small area \\
\hline
\end{tabular}

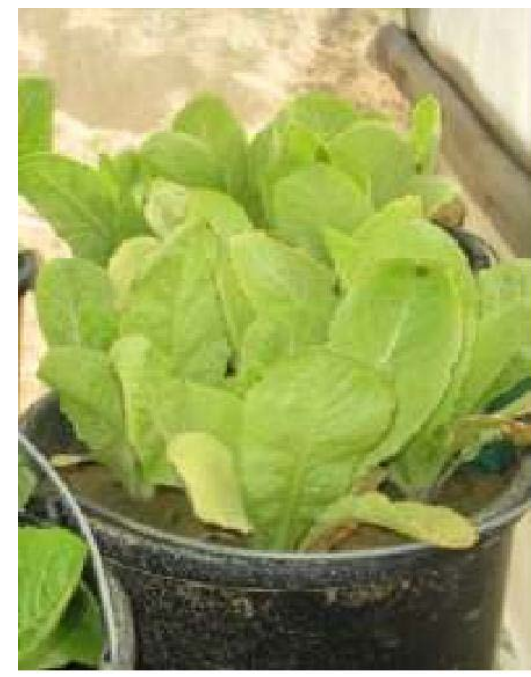

(a)

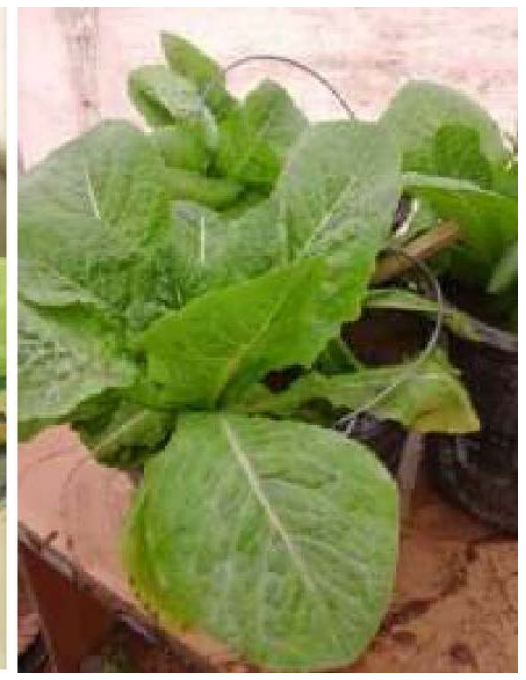

(b)

Figure 6. Influence of digested manure in lettuce biomass grown in pot experiment and treaded with 1 ton manner/hectare.

It can be noticed that biomass of lettuce is increased dramatically due to the use digested manure. It can be noticed that plant biomass increased about $75 \%$ compared to the control sample. Furthermore, the color of the treated plant was dark green whereas the control group was yellow. This indicated the influence of digested manure on the quality of plant growth.

Furthermore, it can be noticed that digested manure dramatically increased plant growth as seen by increased biomass and increased leaf area of lettuce (Figure 6).

\section{Discussion}

The data in Figure 1 clearly show the units of biogas production, operation and purification steps. Moreover, this system is elastic, it can be enlarged to have a high capacity digester or a low capacity one. However, in all cases the manure water mixture should be 10:90 (v/v). Moreover, the black color of the digester is necessary in winter time to enhance the bio-reactions to produce the biogas.

The data in Figure 2 clearly show the biogas production. It can be noticed that biogas production level was small at the beginning time and increased dramatically in due time and reached the maximum after 28 days of operation. This indicated that biogas production is a slowly process. Statistical analysis showed biogas production from poultry manure is the lowest one and the highest pro- 
duction was observed at cow and poultry manure mixtures. Furthermore, strong positive association was found between biogas production and time, $\mathrm{R}^{2}$-value was in the range of $0.9653-0.984$. The explanation of these results is that cow manure contained high fraction of cellulose (carbohydrate materials) which can be converted to methane during the process and chicken manure contained high fraction of protein content which in the biodegradation process can produce amino acids that have $\mathrm{pH}$ buffering capacity in which it can optimize the conversion of carbohydrate to methane. This explanation is supported by the data in Table 1 which showed the $\mathrm{pH}$ profile of Digestate during the biogas production process.

The purification containers are transparent units to be able to visualize the reactions and to make the necessary chemical changes.

The purification process included removal of $\mathrm{H}_{2} \mathrm{~S}, \mathrm{NH}_{3}$ and $\mathrm{CO}_{2}$ according to the following equations

$$
\begin{gathered}
\mathrm{H}_{2} \mathrm{~S}+\mathrm{Fe} \rightarrow \mathrm{FeS} \\
\mathrm{CO}_{2}+\mathrm{Ca}(\mathrm{OH})_{2} \rightarrow \mathrm{CaCO}_{3} \\
\mathrm{NH}_{4} \mathrm{OH}+\mathrm{H}_{3} \mathrm{BO}_{3} \rightarrow \mathrm{BO}_{3}\left(\mathrm{NH}_{3}\right)_{3}
\end{gathered}
$$

These equations are in agreement with El-Nahhal et al., [12] [13] [14] who revealed similar methods for sludge characterization.

The data in Table 1 clearly demonstrated the $\mathrm{pH}$ profile in the bioreactor (digester) during the biogas production. It is obvious that $\mathrm{pH}$ values of all manures are declined form high values (alkaline) to lower value (more acidic). This is related to the nature of manure contents and the biodegrading organisms present in the manure. It is well known in the literature that chicken manure contained different degrading bacteria than cow manure. This suggest different biodegradation process. Moreover, biogas production passes throughout three steps including acidosis.

This is in agreement with previous investigators [27] [28] [29] [30] who demonstrated that biogas production started by biodegradation of carbohydrate, lipids, protein leading to production of organic acids which in turn be converted to acetic acid before methanogensis (biogas production).

The data in Figure 3 clearly showed that chicken manure has the highest values of TS among cow manure and/or mixed manure. The explanation of these results is related to the feeding pattern which usually ate fine stones and sands to help in the digestion process. In due time, TS values were reduced and reached to the lowest level after 28 day of operation. The explanation of these results is that large molecules such as carbohydrate, protein and lipids are being degraded to micromolecules such as oligosaccharides, polypeptides, and trigelesrides then converted to Nano molecules such as organic acids or acetic acid with have the critical rule in biogas production. This explanation is in accordance with Maghanaki et al., [27] who reported similar phenomenon for other cases. Further support to this explanation is obtained from the data on Figure 2 (biogas pro- 
duction). In addition, the data in Figure 4 clearly showed the increased value of $\mathrm{EC}$ of manures in due time. It can be noticed that cow manure has the highest EC value followed by chicken manure whereas mixed manure has the lowest value. The explanation of these results is that cow manure contained cellulose and carbohydrate materials that being degraded to fatty acids that be ionized in the manure and increased the electric conductivity of the solution. On the other hands chicken manure contained high fraction of protein which were being degraded to poly peptides and amino acids which have a high buffering capacity of the manure slurry, this may reduce the electric conductivity of the solution. These results are in agreement with previous reports [31] [32] [33] [34] [35] that showed the biodegration of organic molecules by cyanobacteria.

Moreover, the data in Figure 5 clearly showed the bioremediation process of manure due to biogas production. It is obvious that all type of manures have the same bioremediation trends. The reduction in COD and BOD values are related to the biogas production (Figure 2). However, the reduction of COD and BOD values can be modeled according to the following equations:

$$
\begin{gathered}
\text { ORGANIC MANTTER }+\mathrm{O}_{2} \rightarrow \mathrm{CO}_{2}+\mathrm{H}_{2} \mathrm{O} \\
\text { ORGANIC MANTTER + BACTERA } \rightarrow \mathrm{CO}_{2}+\mathrm{H}_{2} \mathrm{~S}+\mathrm{NH}_{4} \mathrm{OH}+\mathrm{H}_{2} \mathrm{O} \\
\mathrm{CO}_{2}+\text { METHANOGENESIS BACTERIA } \rightarrow \mathrm{CH}_{4}+\mathrm{H}_{2} \mathrm{~S}+\mathrm{NH}_{3}
\end{gathered}
$$

Accordingly removal of COD and BOD is related to biogas productions. This is in agreement with El-Nahhal et al. [36] who showed that removal of COD and BOD form wastewater using sand filer was related to the retention time.

The data in Table 2 clearly show the influence of digested manure on lettuce growth. It is obvious that the biomass was increased by $75 \%$ in the treated pots by digested manure above that of the control group. The explanation of these results is that biodegradation of manure produced fatty acids, amino acids, these acids can react with soil minerals and produced soluble salts that acts as plant nutrients. In addition, at a late stage, the organic molecules can be biomineralized by rhizosphere microorganisms producing $\mathrm{NH}_{4} \mathrm{OH}$ and $\mathrm{H}_{2} \mathrm{~S}$. These molecules can be either absorbed by plants or assimilated in the plant tissue to organic nitrogen or organic sulfur. On the other hands, $\mathrm{NH}_{4} \mathrm{OH} / \mathrm{H}_{2} \mathrm{~S}$ may oxidized by soil oxygen to produce corresponding nitric acid or sulfuric acid that further enhance the solubility of cations in soil environment providing plant with the required nutrients. This explanation is in accordance with previous reports [37]-[42].

\section{Comparison between This Study and Published Work}

A comparison between the present study and those from the literature is presented in Table 3.

It is obvious that the present study dealt with raw cow, chicken and mixed manure whereas published work [28] [29] [30] dealt with a single manure. It is clear that all studies investigated the production of biogas. Purification of biogas 
Table 3. Comparison between our results and those in the literature.

\begin{tabular}{ccccc}
\hline Tested parameter & Present study & $\begin{array}{c}\text { Zhang et al. } \\
{[28]}\end{array}$ & $\begin{array}{c}\text { Böjti et al. } \\
{[29]}\end{array}$ & $\begin{array}{c}\text { Gomaa, and } \\
\text { Abed [30] }\end{array}$ \\
\hline Cow manure & $\sqrt{ }$ & - & - & - \\
Chicken manure & $\sqrt{ }$ & $\sqrt{ }$ & $\sqrt{ }$ & - \\
Mixed manure & $\sqrt{ }$ & - & - & - \\
Fecal & - & - & - & $\sqrt{ }$ \\
Biogas production & $\sqrt{ }$ & $\sqrt{ }$ & - \\
Biogas purification & $\sqrt{ }$ & - & - & - \\
pH & $\sqrt{ }$ & $\sqrt{ }$ & - & - \\
EC & $\sqrt{ }$ & - & - & $\sqrt{ }$ \\
COD status & $\sqrt{ }$ & - & - & - \\
BOD status & $\sqrt{ }$ & - & - & - \\
Bioassay Digested manure & $\sqrt{ }$ & - & - & \\
\hline
\end{tabular}

from the impurities that emerged during the biodegration process was not achieved at any study except the present one which provided a chemical method for purification.

Moreover, the present study determined the physico-chemical properties of manure and provided kinetic evaluation of $\mathrm{pH}, \mathrm{EC}, \mathrm{BOD}, \mathrm{COD}$, whereas other studies provided kinetic evaluation for biogas production only except [28] investigated the $\mathrm{pH}$.

However, the study of Zhang et al. [28] provided valuable information that may be helpful to researchers around the world but all the investigations listed in Table 3 did not show bioassay determination to the digestate at the end of the experimental work except this study provided bioassay technique for the end product.

It can be concluded that the present study integrated the picture of biogas production by providing the value of mixed manure, purification method for the biogas and bioassay technique for the end product. So that this study is opening a new area of investigation in the biogas technology.

\section{Conclusion}

This study showed a simple and easy applicable method for biogas production. Biogas production was tremendously increased by time and reached maximum point after 28 days of operation under laboratory or field conditions. Produced biogas was higher from mixed manure than cow or chicken manner. Chicken manure produced the lowest quantity of biogas. The impurities associated with biogas were removed by chemical method. Reduction of BOD and COD indicated the bioremediation of manures. Application of digested manure as a fertilizer provided higher yield of agricultural production. 


\section{Conflicts of Interest}

The authors declare no conflicts of interest regarding the publication of this paper.

\section{References}

[1] Vindis, P., Mursec, B., Janzekovic, M., Stajnko, D. and Cus, F. (2010) Anaerobic Digestion of Maize Hybrids for Methane Production. Journal of Achievements in Materials and Manufacturing Engineering, 40, 87-94.

[2] Rao, P.V., Baral, S.S., Dey, R. and Mutnuri, S. (2010) Biogas Generation Potential by Anaerobic Digestion for Sustainable Energy Development in India. Renewable and Sustainable Energy Reviews, 14, 2086-2094. https://doi.org/10.1016/j.rser.2010.03.031

[3] Laskri, N. and Nedjah, N. (2015). Comparative Study for Biogas Production from Different Wastes. International Journal of Bio-Science and Bio-Technology, 7, 39-46. https://doi.org/10.14257/ijbsbt.2015.7.4.05

[4] Al-Hamamre, Z., Al-Mater, A., Sweis, F. and Rawajfeh, K. (2014) Assessment of the Status and Outlook of Biomass Energy in Jordan. Energy Conversion and Management, 77, 183-192. https://doi.org/10.1016/j.enconman.2013.09.041

[5] Al Jabri, S.J. and Sharkh, M.S.A. (2013) Generation of Biogas from Bio-Waste in Rural Area of Palestine. International Proceedings of Chemical, Biological and Environmental Engineering (IPCBEE), 57, 57-61.

[6] Marañón, E., Castrillón, L., Quiroga, G., Fernández-Nava, Y., Gómez, L. and García, M. (2012) Co-Digestion of Cattle Manure with Food Waste and Sludge to Increase Biogas Production. Waste Management, 32, 1821-1825. https://doi.org/10.1016/j.wasman.2012.05.033

[7] Esposito, G., Frunzo, L., Panico, A. and Pirozzi, F. (2012) Enhanced Bio-Methane Production from Co-Digestion of Different Organic Wastes. Environmental Technology, 33, 2733-2740. https://doi.org/10.1080/09593330.2012.676077

[8] Hamed, T.A., Flamm, H. and Azraq, M. (2012) Renewable Energy in the Palestinian Territories: Opportunities and Challenges. Renewable and Sustainable Energy Reviews, 16, 1082-1088. https://doi.org/10.1016/j.rser.2011.10.011

[9] Al-Amin, A.M., Al-Shaw, F. and Al-Gadban, S. (2007) Design, Install and Apply the Biogas Unit At the Faculty of Agriculture (Kharabo) Farm Damascus University Journal of Damascus University for Agriculture Science, 23, 390-379.

[10] Mata-Alvarez, J. (2002) Fundamentals of the Anaerobic Digestion Process Biomethanization of the Organic Fraction of Municipal Solid Wastes. IWA Publishing Company, London.

[11] Nelson, C. and Lamb, J. (2002) Final Report: Haubenschild Farms Anaerobic Digester, Updated. The Minnesota Project, St. Paul, MN.

[12] El-Nahhal, I., Al-Najar, H. and El-Nahhal, Y. (2014) Physicochemical Properties of Sewage Sludge from Gaza. International Journal of Geosciences, 5, 586-594. https://doi.org/10.4236/ijg.2014.56053

[13] El-Nahhal, I., Al-Najar, H. and El-Nahhal, Y. (2014) Cations and Anions in Sewage Sludge from Gaza Waste Water Treatment Plant. American Journal of Analytical Chemistry, 5, 655-665. https://doi.org/10.4236/ajac.2014.510073

[14] El-Nahhal, Y., Safi, M., Tubail, K. and Safi, J. (2013) Effect of Treated Waste Water Irrigation on Plant Growth and Soil Properties in Gaza Strip Palestine. American 
Journal of Plant Science, 4, 1736-1743. https://doi.org/10.4236/ajps.2013.49213

[15] Ministry of Agriculture 2015.

[16] El-Nahhal, Y., Nir, S., Polubesova, T., Margulies, L. and Rubin, B. (1999) Movement of Metolachlor in Soil: Effect of Organo-Clay Formulation. Pesticide Science, 55, 857-864. https://doi.org/10.1002/(SICI)1096-9063(199908)55:8<857::AID-PS24>3.0.CO;2-P

[17] El-Nahhal, Y., Nir, S., Polubesova, T., Margulies, L. and Rubin, B. (1998) Leaching, Phytotoxicity and Weed Control of New Formulations of Alachlor. Journal of Agricultural Food Chemistry, 46, 3305-3313. https://doi.org/10.1021/jf971062k

[18] El-Nahhal, Y. (2003) Persistence, Mobility, Efficacy and Safety of Chloroacetanilide Herbicide Formulation under Field Conditions. Environmental Pollution, 124, 33-38. https://doi.org/10.1016/S0269-7491(02)00431-1

[19] El-Nahhal, Y. (2003) Adsorption Mechanism of Chloroacetanilide Herbicides to Modified Montmorillonite. Journal of Environmental Science and Health B, 38, 591-604. https://doi.org/10.1081/PFC-120023517

[20] El-Nahhal, Y. and Hamdona, N. (2015) Phytotoxicity of Alachlor, Bromacil and Diuron as Single or Mixed Herbicides Applied to Wheat, Melon, and Molokhia. SpringerPlus, 4, 364. https://doi.org/10.1186/s40064-015-1148-7

[21] El-Nahhal, Y. and Hamdona, N. (2017) Adsorption, Leaching and Phytotoxicity of Some Herbicides as Single and Mixtures to Some Crops. Journal of the Association of Arab Universities for Basic and Applied Sciences, 22, 17-25.

https://doi.org/10.1016/j.jaubas.2016.01.001

[22] El-Nahhal, Y., EL-dahdouh, N., Hamdona, N. and Alshanti, A. (2016) Toxicological Data of Some Antibiotics and Pesticides to Fish, Mosquitoes, Cyanobacterial Mats and to Plants. Data in Brief, 6, 871-880. https://doi.org/10.1016/j.dib.2016.01.051

[23] Heinze, S., Chen, Y., El-Nahhal, Y., Hadar, Y., Jung, R., Safi, J., Safi, M., Tarchitzky, J. and Marschner, B. (2014) Small Scale Stratification of Microbial Activity Parameters in Mediterranean Soils under Freshwater and Treated Wastewater Irrigation. Soil Biology and Biochemistry, 70, 193-204. https://doi.org/10.1016/j.soilbio.2013.12.023

[24] El-Nahhal, Y. (2017) A New Field Protocol for Determination of Forest Structure, Biodiversity and Heath Status by Means of GPS Tools: A Case Study from Gaza Forest. Open Journal of Ecology, 7, 69-83. https://doi.org/10.4236/oje.2017.71006

[25] Alloh, M.O., AL-Kurdi, S., Alagha, M.R. and Yasser, E.-N. (2018) Nemacur Residue Analysis in Soil Water and Cucumber Samples Collected from the Field in Gaza Strip, Palestine. American Journal of Plant Sciences, 9, 517-530. https://doi.org/10.4236/ajps.2018.93039

[26] Al-Kurdi, S., Al-Louh, M.O., Al-Agha, M.R. and El-Nahhal, Y. (2018) Development of Analytical Method for the Detection of Nemacur Residues in Cucumber Fruits. American Journal of Analytical Chemistry, 9, 64-76. https://doi.org/10.4236/ajac.2018.91006

[27] Maghanaki, M.M., Ghobadian, B., Najafi, G. and Galogah, R.J. (2013) Potential of Biogas Production in Iran. Renewable and Sustainable Energy Reviews, 28, 702-714. https://doi.org/10.1016/j.rser.2013.08.021

[28] Zhang, W., Lang, Q., Pan, Z., Jiang, Y., Liebetrau, J., Nelles, M., Dong, H. and Dong, R. (2017) Performance Evaluation of a Novel Anaerobic Digestion Operation Process for Treating High-Solids Content Chicken Manure: Effect of Reduction of the Hydraulic Retention Time at a Constant Organic Loading Rate. 
[29] Böjti, T., Kovács, K.L., Kakuk, B., Wirth, R., Rákhely, G. and Bagi, Z. (2017) Pretreatment of Poultry Manure for Efficient Biogas Production as Monosubstrate or Co-Fermentation with Maize Silage and Corn Stover. Anaerobe, 46, 138-145. https://doi.org/10.1016/j.anaerobe.2017.03.017

[30] Gomaa, A.M. and Abed, M.M.R. (2017) Potential of Fecal Waste for the Production of Biomethane, Bioethanol and Biodiesel. Journal of Biotechnology, 253, 14-22. https://doi.org/10.1016/j.jbiotec.2017.05.013

[31] Safi, J., Awad, Y. and El-Nahhal, Y. (2014) Bioremediation of Diuron in Soil and by Cyanobacterial Mat. American Journal of Plant Sciences, 5, 1081-1089. https://doi.org/10.4236/ajps.2014.58120

[32] El-Nahhal, Y., Awad, Y. and Safi, J. (2013) Bioremediation of Acetochlor in Soil and Water Systems by Cyanobacterial Mat. International Journal of Geosciences, 4, 880-890. https://doi.org/10.4236/ijg.2013.45082

[33] Abed, M.A., Safi, M.N., Köster, J., Beer, D., El-Nahhal, Y., Rullkötter, J. and Garcia-Pichel, F. (2002) Microbial Diversity of a Heavily Polluted Microbial Mat and Its Community Changes Following Degradation of Petroleum Compounds. Applied Environmental Microbiology, 68, 1674-1683. https://doi.org/10.1128/AEM.68.4.1674-1683.2002

[34] EL-Nahhal, Y., Kerkez, M.F.S. and Abu Heen, Z. (2015) Toxicity of Diuron, Diquat and Terbutryn Cyanobacterial Mats. Ecotoxicology and Environmental Contamination, 10, 71-82. https://doi.org/10.5132/eec.2015.01.11

[35] El-Nahhal, Y. and Hamms, Sh. (2017) Effects of Bromacil, Malathion and Thiabendazole on Cyanobacteria Mat Growth. International Journal of Applied Science-Research and Review, 4, 1-9.

[36] El-Nahhal, Y., El-Dahdouh, O. and Al-Najar, H. (2017) Influence of Sand Filter in Wastewater Treatment (a Case Study in Gaza City, Gaza Strip Wastewater Treatment Plant). Desalination and Water Treatment, 89, 118-126. https://doi.org/10.5004/dwt.2017.21398

[37] El-Nahhal, Y., Abadsa, M. and Affifi, S. (2014) Leaching Potential of Diuron and Linuron in Gaza Soils. American Journal of Plant Sciences, 5, 4040-4049.

[38] El-Nahhal, Y., Lagaly, G. and Rabinovitz, O. (2005) Organo-Clay Formulations of Acetochlor: Effect of High Salt. Journal of Agricultural and Food Chemistry, 53, 1620-1624. https://doi.org/10.1021/jf040383a

[39] El-Nahhal, Y. (2004) Contamination and Safety Status of Plant Food in Arab Countries. Journal of Applied Science, 4, 411-417. https://doi.org/10.3923/jas.2004.411.417

[40] El-Nahhal, Y. (2004) Leaching Behavior of Metolachlor in Soil. Journal of Environmental Engineering \& Science, 3, 187-194. https://doi.org/10.1139/s03-075

[41] El-Nahhal, Y. and Safi, J. (2005) Adsorption of Benzene and Naphthalene to Modified Montmorillonite. Journal of Food, Agriculture and Environment, 3, 295-298

[42] Kaschl, A., El-Nahhal, Y., Abu Mourad, T., Tubail, Kh., Safi, J., Hadar, Y., Chen, Y. and Roemheld, V. (1998) Long-Term Field Experiment to Examine the Agricultural Application of Municipal Solid Waste Compost in the Gaza Strip. KongreBband VDLUFA-Schriftenreihe Germany, 49, 251-254. 